Canadian Journal of Bioethics

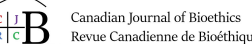

Revue canadienne de bioéthique

\title{
Review of: Cooper, D.B. (ed.) (2017) Ethics in Mental Health-Substance Use
}

\section{Zoe Bernatsky}

Volume 1, Number 2, 2018

URI: https://id.erudit.org/iderudit/1058284ar

DOI: https://doi.org/10.7202/1058284ar

See table of contents

Publisher(s)

Programmes de bioéthique, École de santé publique de l'Université de

Montréal

ISSN

2561-4665 (digital)

Explore this journal

Cite this review

Bernatsky, Z. (2018). Review of [Review of: Cooper, D.B. (ed.) (2017) Ethics in Mental Health-Substance Use]. Canadian Journal of Bioethics / Revue canadienne de bioéthique, 1(2), 78-79. https://doi.org/10.7202/1058284ar 


\title{
Review of: Cooper, D.B. (ed.) (2017) Ethics in Mental Health-Substance Use
}

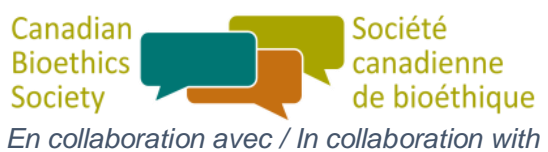

Zoe Bernatsky ${ }^{1}$

Mots clés

santé mentale, toxicomanie, éthique

\author{
Keywords \\ mental health, substance use, ethics
}

Research demonstrates that approximately $50 \%$ of American adults who experience mental health or substance-use issues face both mental health and substance use challenges [1]. Ethics in Mental Health-Substance Use [2] employs a multidisciplinary and holistic method to explore challenges that affect the lives of individuals with mental health and substance use issues and those who love and care for them. The authors, which include nurses, physicians, psychologists, ethicists and lawyers, outline challenges such as the assessment of capacity for treatment in "high-stakes" treatment choices such as electroconvulsive therapy or medical assistance in dying, since mental health conditions and substance use can impact the capacity to confer consent for such treatment. Principles related to contemporary issues such as harm reduction and respect for boundaries within dual relationships are introduced, making this book a particularly useful guide for practitioners and ethicists new to this field of practice.

The book is set up in a concise format with case studies, interactive exercises, and guiding questions for self-assessment. Chapters 1-3 introduce ethical frameworks to guide professional practice. These include reflective approaches, such as virtue and care ethics, and instrumental approaches, such as the utilitarian, deontological or four principles approach. Cases are used to underscore that in some situations, the 'best' option is not readily obvious or achievable. Chapters 4-7 highlight the need for practitioners to acquire skills and dispositions such as cultural sensitivity, compassion, respect, and dignity, in order to be effective in their work with these often vulnerable and stigmatized individuals. I was particularly impressed by Chapter 8 which explores a way forward, using a virtue framework. Here, practitioners are encouraged to exercise practical wisdom arising from moral skill (rooted in experience and reflection) and moral will (based in doing what is right for the right reasons) as they encounter persons with complex stories and multifaceted challenges. Chapters 9-15 focus on challenges related to policy development which include human rights issues such as informed consent, abstinence vs. harm reduction approaches, the importance of gender sensitive services, and difficulties employing "gold-standard" research techniques. The critical challenge of evaluation of capacity for consent and self-determination are central matters of ethical concern, particularly when there is a threat to self or others, or when the benefits of treatment are uncertain and the burdens significant (e.g., the use of electroconvulsive therapy). Finally, chapters 16-21 relate to the special concerns of younger and older individuals, high-risk sexual behaviour, cannabis use, palliative care and assisted death.

Ethics in Mental Health-Substance Use is a must read for those who work in the field of mental health and substance use, especially for professionals new to this area. The use of realistic case studies provides an opportunity to better understand ethical principles and frameworks and how they can be employed in the pursuit of holistic health of individuals with mental health and substance use challenges. Reflective exercises are also well-suited for professional development. Senior leadership and policy developers who have mental health and substance use within a larger portfolio and whose responsibility it is to be informed about ethical concerns related to research and practice, will also find this book helpful. Limitations include the fact that no patient was a chapter author and proficient practitioners might already be familiar with the content, however, the multi-disciplinary patient-centred approach is refreshing and makes the text a very helpful addition to the Mental Health-Substance Use series. Cooper and his colleagues make an important contribution to the field of mental health, substance use and ethics by surveying the field and outlining the most critical themes in the field today.

Conflit d'intérêts

Aucun déclaré

Édition/Editors: Angel Petropanagos \& Patrick Gogognon
Conflicts of Interest

None to declare

\author{
Affiliations \\ ${ }^{1}$ Newman Theological College, Edmonton, Canada
}

Correspondance / Correspondence: Zoe Bernatsky, Zoe.Bernatsky@newman.edu

Reçu/Received: 9 Oct 2018 Publié/Published: 25 Oct 2018 (CBS/SCB: May 2018)

Les éditeurs suivront les recommandations et les procédures décrites dans le Code of Conduct and Best Practice Guidelines for Journal Editors de COPE. Plus précisément, ils travaillent pour s'assurer des plus hautes normes éthiques de la publication, y compris l'identification et la gestion des conflits d'intérêts (pour les éditeurs et pour les auteurs), la juste évaluation des manuscrits et la publication de manuscrits qui répondent aux normes d'excellence de la revue.
The editors follow the recommendations and procedures outlined in the COPE Code of Conduct and Best Practice Guidelines for Journal Editors. Specifically, the editors will work to ensure the highest ethical standards of publication, including: the identification and management of conflicts of interest (for editors and for authors), the fair evaluation of manuscripts, and the publication of manuscripts that meet the journal's standards of excellence. 


\section{References}

1. Fisher C-M, Simmelink McCleary J, Dimock P, Rohovit J. Provider preparedness for treatment of co-occurring disorders: comparison of social workers and alcohol and drug counselors Social Work Education 2014;33(5):626641.

2. Cooper, D.B. (ed.) Ethics in Mental Health-Substance Use. New York: Taylor and Francis, 2017. 